\title{
Impact on Proline Content of Sugarcane (Saccharum officinarum L.) under Salinity Stress
}

\author{
Ranjana Singh ${ }^{*}$ and R. S. Sengar \\ College of Agriculture, Department of Agri. Biotechnology, Sardar Vallabh Bhai Patel \\ University of Agriculture \& Technology, Meerut, India \\ *Corresponding author
}

\section{Keywords}

Salinity, Proline, Abiotic stress,

Formative stage,

Grand growth stage

Article Info

Accepted:

26 September 2020

Available Online:

10 October 2020

\begin{abstract}
A B S T R A C T
For sustainable production of sugarcane, healthy and more acclimatized plants should be developed that can easily cope up all the environmental barriers of biotic and abiotic stress. Soil salinization is one of these kinds of stress that limits the productivity of crops worldwide. We have investigated the proline content of plant under normal and two different levels of salt irrigation water (ECiw10 $\mathrm{dSm}^{-1}$ and ECiw $20 \mathrm{dSm}^{-1}$ ) consecutively for two years of crop production in 2015-16 and 2016-17. Ten sugarcane varieties (Co 0118, Co 0238, Co 5011, CoLk 99270, CoS 8279, CoSe 8457, Co 5009, CoS 7250, CoPant 97222, Co 98014) were planted in the replicate of three under complete randomized design. Salt treatments were given at formative stage and the tests were performed at grand growth stage of plant life cycle. Effect of salinity can be seen on other phenotypic factors of plant also in correlation with proline. On exposure to salt stress, tolerant varieties CoPant 97222, CoS 7250, Co 98014 were found to accumulate more proline than to varieties Co 0238, CoSe 8457 and Co 0118, while CoS 8279, Co 5011 and Co 5009 show moderate behavior.
\end{abstract}

\section{Introduction}

Sugarcane (Saccharum officinarum L.) is a glycophytic plant, belongs to family poaceae known to be cultivated in the tropical and subtropical regions worldwide. Brazil ranks first position in the world with respect to area (10.2 M ha) and production (768.67 MT) followed by India both in area (4.5 Mha) and production (348.44 MT) (FAOSTAT, 2016). Temperature range for its growth for different stages varies from $18^{\circ}$ to $40^{\circ} \mathrm{C}$. It has certain stages in its life cycle, where the application of water pays large dividends. Onset of tillering, elongation of internode and grand growth phase are the most crucial stage in a crop life cycle that need adequate amount of water (Srivastava and Rai, 2012). Salinity affect crop productivity by disturbing the plant basic phenomenon of growth and development like germination, vegetative and reproductive stages (Basalah, 2010 and Grewal, 2010, Granja et al., 2018). Salinity causes physical drought in soil and hinders the water uptake of plant leads to ionic toxicity, osmotic stress and nutrient 
deficiency in plants from the soil (Shrivastava and Kumar, 2015).Basic problem behind salinity is, it decreases the soil osmotic potential by which sodium and chloride toxicity increases and water availability to plants decreases (Taiz et al., 2017; Simões et al., 2019). Several studies show that proline biosynthesis gene is induced on salinity stress that leads to its accumulation in plant (Simões et al., 2019), also it rapidly accumulates in plants subjected to water or osmotic stress and cold stress (Verslues et al., 2006). Green leaves are the site of its accumulation rather than nonphotosynthetic tissues of stressed plant (Perez-Perez et al., 2009). Normally, proline remain in low amount in plant and increased as salinity or other stress increases. We can say by this that plant that accumulate more proline in stressed condition are the tolerant and vice-versa. Up to $50 \%$ decrease in crop yield is noticed with EC of $10.4 \mathrm{dSm}^{-1}$ (Santana et al., 2006; Granja et al., 2018).). Essential nutrient are being taken by the plant roots in the form of soluble salts from the soil but its excessive accumulation inhibits the growth and development of plant. As per FAO 2015, a total of $800 \mathrm{MHa}$ of land and 32 $\mathrm{MHa}$ of agricultural land are affected by salt stress.

With high evaporation and low precipitation rate crop plants in arid and semiarid zones are also getting affected by high salt stress (de AzevedoNeto et al., 2006; Ahmad et al., 2012). But in reality each climatic zone is more or less affected by the stress (Bhuttaet al., 2004; Rengasamy, 2006). To held out against the salinity stress, plants amass the compatible solutes like proline, that reduces the cytoplasmic osmotic potential of plant cell, hence increase water absorption and scavenging reactive oxygen species (ROS) molecules (Qureshi et al., 2013; Pottosin et al., 2014; Gharsallah et al., 2016). in present study, we have investigated the proline content of plant under salinity and control condition for two consecutive years to observe the pattern if any change persists and also the effect on plant development.

\section{Materials and Methods}

Plant material were taken from Field laboratory and Experiment station of Sardar Vallabh Bhai Patel University of Agriculture \& Technology Meerut, (U.P.), to which ten commercially used sugarcane varieties viz. Co 0118, Co 0238, Co 5011, CoLk 99270, CoS 8279, CoSe 8457, Co 5009, CoS 7250, CoPant 97222, Co 98014, were grown under two different levels of salinity, ECiw(Electrical conductivity of irrigation water) $10 \mathrm{dSm}^{-1}$ and ECiw $20 \mathrm{dSm}^{-1}$ along with the control with three replication in CRD (complete randomized design). EC of irrigation water was maintained by specific ratio of $3: 1: 2$, of $\mathrm{NaCl}, \mathrm{Na}_{2} \mathrm{SO}_{4}, \mathrm{CaCl}_{2} \cdot 2 \mathrm{H}_{2} \mathrm{O}$ at the formative stage of plant and data for evaluation were taken at grand growth phase. Initial $\mathrm{pH}$ of soil was maintained at 6.2 and ECe (Electrical conductivity of the extract of a saturated soil paste) $1.39 \mathrm{dSm}^{-1}$.

\section{Proline content}

Proline content was estimated by the method of Bates et al., (1973).

\section{Reagents}

Aqueous sulfosalicylic acid (3\% w/v)

Glacial acetic acid

Toluene

Acid ninhydrin reagent: $1.25 \mathrm{~g}$ of ninhydrin mixed with $30 \mathrm{ml}$ of glacial acetic acid and 20 $\mathrm{ml}$ of $6 \mathrm{M}$ phosphoric acid.

\section{Procedure}

$500 \mathrm{mg}$ of fresh leaves were homogenized in $10 \mathrm{ml}$ of aqueous sulfosalicylic acid (3\%) and then centrifuge at $4000 \mathrm{rpm}$ for 20 minutes. 2 
$\mathrm{ml}$ of this aliquot was transferred into test tube and $2 \mathrm{ml}$ of acid ninhydrin reagent were added in each test tube. The mixture was heated on boiling water bath for 1 hours, after which reaction was terminated by placing the test tubes in ice box for cooling. Thereafter, the reaction mixture was shaken vigorously with $4 \mathrm{ml}$ toluene and kept for $1 \mathrm{hr}$ till the two layers formed. Chromatophore was thus extracted into toluene phase, (upper layer) was separated and its absorbance was measured at $520 \mathrm{~nm}$ using toluene as blank. L-Proline standard was used for quantification and the proline content in the sample was calculated using the formula.

Proline $(\mathrm{mg} / \mathrm{g}$ fresh weight $)=\frac{36.2311 \times \text { O.D x V }}{2 \times \mathrm{W}}$

Where, $\mathrm{W}=$ Fresh weight of leaf in $\mathrm{mg}, \mathrm{O} . \mathrm{D}$. $=$ Optical density at $520 \mathrm{~nm}$ and $\mathrm{V}=$ total volume of extract in $\mathrm{ml}, 2=$ Volume of aliquot taken for proline estimation in alkali and reduction of phosphomolybdic tungstate reagent by the tyrosine and tryptophan present in the treated protein.

\section{Statistical Analysis}

The data was subjected to statistical analysis using OPSTAT-1, SPSS (version 19.02), with significance at $P \leq 0.05$.

\section{Results and Discussion}

Osmotic stress and ion toxicity are the two prominent factors result due to $\mathrm{NaCl}$ stress. Normally, plant cells have higher osmotic pressure than to soil so it takes water and minerals from the soil but in case of salinity stress the osmotic potential of soil increases by the high aggregation of salt in the soil that makes plant unable to take water and essential minerals from the soil. This condition creates a condition of physiological drought in soil (Munnus et al., 2006; Bagum and Islam,
2015). In present study, we find that proline accumulate more in tolerant verities rather than susceptible plant when expose to salinity and its level further increases when we increase the EC of irrigation water respectively (Figure 1 and 2), control plant show less proline in their cell that signifies that plant under stress condition amass more proline in the cell as compared to non-stressed plant. Correlation of phenotypic traits with proline shows significant values of the mean pool data of two consecutive years (Table 1). Morphologically, plants show various symptoms under saline condition that truly proves the adverse effect of salinity on plant like plant growth reduction, decrease in length of internodes, cane girth and juice quality etc. (Hussain et al., 2004). Plants physiological and biochemical activity suffers due to disruption of anabolic and catabolic phenomenon (Corchete and Guerra, 1986; Torres-Schuman et al., 1989). Sugarcane plant has categorized as moderately sensitive towards salt stress (Shannon, 1997) and each plant or variety responds differently to salt stress due to their genotypic difference. Mahajan et al., (2013) examined the effect of salt stress on ten sugarcane genotypes viz., Co 94012, CoC 671, Co 740, CoM 0265, Co 86032, Co 9012, CoC 08026, CoM 08086, CoM 08011 and MS 08002, cultivated in three varying soil conditions viz., normal, saline and sodic soils, that were evaluated for the effect of salt stress on various factors like glycine betaine, proline, soluble protein contents, nitrate reductase activity and pyrroline-5-carboxylate synthase activity. The result revealed the increased accumulation of proline, glycine betaine, soluble protein and increased activity of pyrroline-5-carboxylate synthase activity in sodic soil can be used as biochemical markers for screening the efficient genotype of sugarcane for salt tolerance. Tolerant genotypes accumulate large amount of compatible solute that maintains the turgor pressure of cells eg. 
glycinbetaine, free proline, sugar and polyols, above all, proline protects the cell from the ROS generated due to high salt induction (Jain et al., 2001). Some studies suggest that exogenous application of proline to stressed plant reduces the stress through ameliorating antioxidant activities and supressing sodium and chloride uptake with increase in potassium assimilation of plants (Heuer, 2010). In case of maize, on foliar spray plant growth and yield increases (Alam et al., 2016). In B. juncea plants antioxidant enzymes like catalase, peroxidase and superoxide dismutase activity increases with decrease in electrolyte leakage on applying proline (Wani et al., 2016; El Moukhtari et al., 2020). Anthony (1979), while investigating proline accumulation in eight species of marsh halophytes subjected to increasing salinity, found that plants accumulate proline only after attaining a threshold salinity level. Present study categorize the ten verities into tolerant varieties like CoPant 97222, CoS 7250, Co 98014 that accumulate more proline, moderate CoS 8279, Co 5011 and Co 5009and susceptible varieties Co 0238, CoSe 8457 and Co 0118 in which is accumulation is less.

Table.1 Correlation table based on the pool mean data of two consecutive years for phenotypic traits with proline under control and salinity, S1-10 dSm ${ }^{-1}$ and S2-ECiw $20 \mathrm{dSm}^{-1}$ conditions for the year 2015-16 and 2016-17

\begin{tabular}{|c|c|c|c|c|c|c|c|c|}
\hline & PH & CG & NTPH & INPP & LA & INTL & LAI & PC \\
\hline PH C & 1 & & & & & & & \\
\hline S1 & 1 & & & & & & & \\
\hline S2 & 1 & & & & & & & \\
\hline CG C & $.635^{*}$ & 1 & & & & & & \\
\hline S1 & $.682 *$ & 1 & & & & & & \\
\hline S2 & $.750 *$ & 1 & & & & & & \\
\hline NTPH C & .547 & $.660 *$ & 1 & & & & & \\
\hline S1 & $.766^{* *}$ & $.964 * *$ & 1 & & & & & \\
\hline S2 & $.813 * *$ & $.971 * *$ & 1 & & & & & \\
\hline INPP C & .524 & .566 & $.940 * *$ & 1 & & & & \\
\hline S1 & $.749 *$ & $.941 * *$ & $.969 * *$ & 1 & & & & \\
\hline S2 & $.841 * *$ & $.965 * *$ & $.976^{* *}$ & 1 & & & & \\
\hline LA C & .444 & .616 & $.647^{*}$ & $.692 *$ & 1 & & & \\
\hline S1 & $.655^{*}$ & $.980 * *$ & $.968 * *$ & $.927 * *$ & 1 & & & \\
\hline S2 & $.690 *$ & $.918 * *$ & $.935^{* *}$ & $.942 * *$ & 1 & & & \\
\hline INTL C & $.737 *$ & $.673^{*}$ & $.953 * *$ & $.927 * *$ & $.676^{*}$ & 1 & & \\
\hline S1 & $.742 *$ & $.925 * *$ & $.968 * *$ & $.918 * *$ & $.941 * *$ & 1 & & \\
\hline S2 & $.814 * *$ & $.954 * *$ & $.966^{* *}$ & $.953 * *$ & $.892 * *$ & 1 & & \\
\hline LAI C & .104 & .424 & .182 & .212 & .444 & .074 & 1 & \\
\hline S1 & .477 & $.632 *$ & .478 & .473 & .516 & .392 & 1 & \\
\hline S2 & $.698 *$ & $.757^{*}$ & $.831 * *$ & $.782 * *$ & $.798 * *$ & $.838 * *$ & 1 & \\
\hline PC C & $.882 * *$ & $.685^{*}$ & .493 & .578 & .481 & $.659 *$ & .272 & 1 \\
\hline S1 & $.673 *$ & $.637^{*}$ & $.692 *$ & $.777 * *$ & .544 & .583 & .481 & 1 \\
\hline S2 & $.800 * *$ & $.732 *$ & $.722 *$ & $.679 *$ & .506 & $.803 * *$ & $.664 *$ & 1 \\
\hline
\end{tabular}

*Correlation is significant at the 0.05 level (2-tailed)

**Correlation is significant at the 0.01 level (2-tailed) 
Fig.1 Proline estimation of ten sugarcane genotypes under control and salinity $\left(10 \mathrm{dSm}^{-1}\right.$ and ECiw $20 \mathrm{dSm}^{-1}$ ) conditions for the year 2015-16

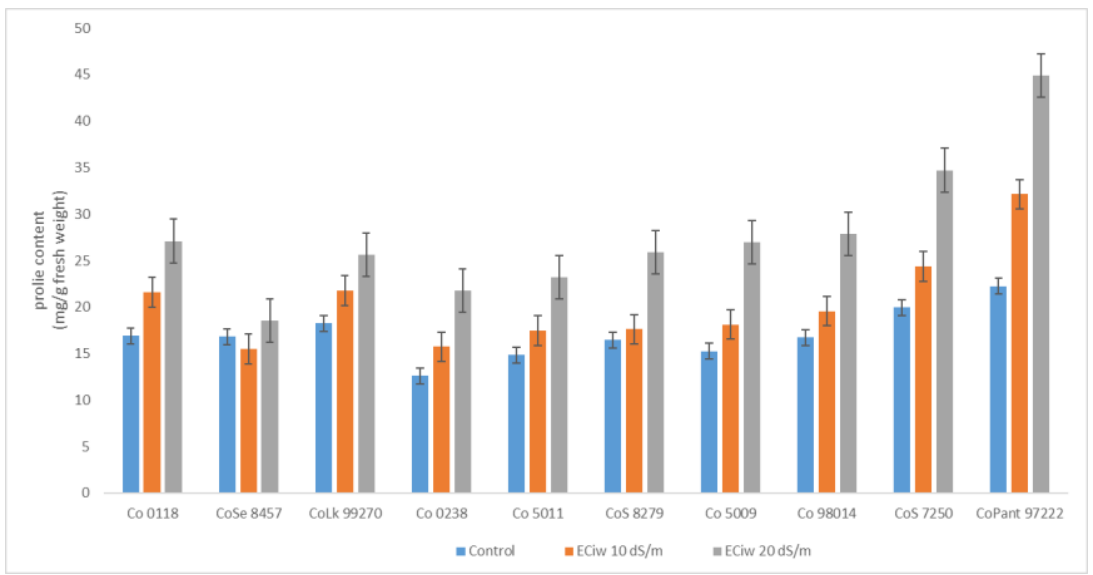

Fig.2 Proline estimation of ten sugarcane genotypes under control and salinity $\left(10 \mathrm{dSm}^{-1}\right.$ and ECiw $20 \mathrm{dSm}^{-1}$ ) conditions for the year 2016-17

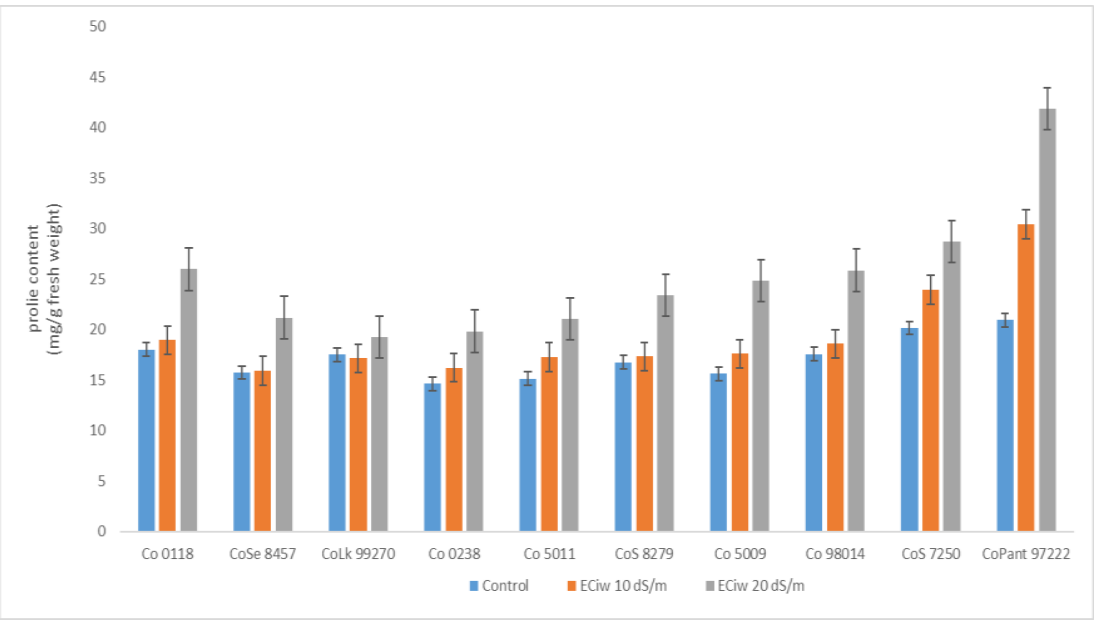

In conclusions due to salinity, water potential falls and solutes accumulate in the cell. Subsequently, the cell facilitates water towards it from the surrounding medium and stabilizes turgor pressure. Accumulation of $\mathrm{K}^{+}$, proline and sugar content enhances in tolerant line of sugarcane cultivar by the osmotic adjustment of leaf cells that reduces osmotic and leaf water potential of the tolerant plant as compared to sensitive plant. Being cytoplasmic solute, amino acid accumulates in the cell and its increase amount serves for osmotic adjustment under salinity. Accumulation ofproline creates differences in osmotic potential that implies varietal difference in genetic level. Sugarcane is a perennial crop plant, if we discover the stage at which plant can adapt easily against stress it would be beneficial to screen out the genotypes for salinity tolerance. If one can understand the mechanism of sugarcane plant involve in physio-biochemical adaptation at different growth stages it will be profitable to enhance the cultivation of stress tolerant plant through genetic improvement strategies like biotechnological approach or conventional breeding techniques. 


\section{Acknowledgment}

Authors are thankful to the Vice-chancellor and Director Research SVPUA\&T Meerut, U.P. for providing the required facilities to conduct the present research work.

\section{Abbreviations}

PH- plant height

CG- cane girth

NTPH- number of tillers per hill

INPP- internode per plant

LA- leaf area per plant

INTL- intermodal length

LAI- leaf area index

PC- proline content

\section{References}

Ahmad, K., Saqib, M., Akhtar, J., and Ahmad, R. 2012. Evaluation and characterization of genetic variation in maize (Zea mays L.) for salinity tolerance. Pakistan Journal of Agricultural Sciences. 49, 521-526.

Alam, R., Das, D., Islam, M., Murata, Y., and Hoque, M. 2016. Exogenous proline enhances nutrient uptake and confers tolerance to salt stress in maize (Zea mays L.). Progr. Agric. 27, 409-417.

Anthony, J. C., and Anthony, H. C. 1979. Evaluation of proline accumulation in the adaptation of diverse species of marsh halophytes to the saline environment. American Journal of Botany. 66 (3), 307 312.

Basalah, M.O., 2010. Action of salinity on seed germination and seedling growth of Solanum melongena L. J Agric Res Kafer El-Sheikh. 36:64-73.

Bates, L. S., Waldren, R. P., and Teare, J. D. 1973. Rapid determination of free proline for water stress studies. Plant and Soil. 39, 205-208.

Begum, K., and Islam, O.M. 2015. Selection of salt tolerant somaclones for development of salt stress tolerant varieties. Plant. 3 (4), 37-46.

Bhutta, W. M., Ibrahim, M., Akhtar, J., Shahzad,
A., Haq, T.U., and Haq, M.A.U. 2004. Comparative performance of sunflower (Helianthus annuus L.) genotypes against $\mathrm{NaCl}$ salinity. Santa Cruz do Sul. 16, 718.

Corchete, P., and Guerra, H. 1986. Effect of $\mathrm{NaCl}$ and polyethylene glycol on solute content and glycosidase activities during germination of lentil seeds. Plant, Cell and Environment. 9(7), 589-593.

de Azevedo-Neto A. D., Prisco, J.T., Eneas, J., Abreu, C. E. B. De., and Gomes-Filho, E. 2006. Effect of salt stress on antioxidative enzymes and lipid peroxidation in leaves and roots of salt-tolerant and salt sensitive maize varieties. Environmental and Experimental Botany. 56, 87-94.

El Moukhtari, A., Cabassa-Hourton, C., Farissi,M., and Savoure, A. 2020. How does proline treatment promote salt stress tolerance during crop plant development. Frontiers in Plant Science. 11, Article 1127.

FAO. 2015. Technical issues of salt-affected soils. FAOSTAT. 2016. Statistical Division: Production domain- Crops.

Gharsallah,C., Fakhfakh, H., Grubb, D., and Gorsane, F. 2016. Effect of salt stress on ion concentration, proline content, Antioxidant enzyme activities and gene expression in Tomato cultivars. AOB Plants, 8, plw 055.

Granja, M.M.C., Medeiros, M.J.L., Silva, M.M.A., Camara, T.R., Willadino, L., and Ulisses, C. 2018. Response to in vitro salt stress in sugarcane is conditioned by concentration and condition of exposure to $\mathrm{NaCl}$. Acta biol. Colomb, 23(1), 30-38.

Grewal, H. S., 2010. Water uptake, water use efficiency, plant growth and ionic balance of wheat, barley, canola and chickpea plants on a sodic vertosol with variable subsoil $\mathrm{NaCl}$ salinity. Agric Water Manag. 97:148-156.

Heuer, B. (2010). "Role of proline in plant response to drought and salinity," in Handbook of Plant and Crop Stress, 3rd ed. Ed. A. Pessarakli (Boca Raton: CRC Press), 213-238.

Hussain, A., Khan, Z. I., Ashraf, M., Rashid, M. H., and Akhtar, M. S. 2004. Effect of salt 
stress on some growth attributes of sugarcane cultivars $\mathrm{CP}-77-400$ and COJ84. Int J Agric Biol. 6, 188-191.

Jain, M., Mathur, G., Koul, S., and Sarin, N. 2001. Ameliorative effects of proline on salt stress-induced lipid peroxidation in cell lines of groundnut (Arachis hypogaea L.). Plant Cell Reports. 20(5), 463-468.

Munns, R., James, R. A., and Läuchli, A. 2006. Approaches to increasing the salt tolerance of wheat and other cereals. Journal of Experimental Botany. 57, 10251043.

Perez-Perez, J. G., Robles, J. M., Tovar, J. C., and Botia, P. 2009. Response to drought and salt stress of lemon 'Fino 49' under field conditions: water relations, osmotic adjustment and gas exchange. Sci Hortic. 122, 83-90.

Pottosin, I., Velarde-Buend_1a, A.M., Bose, J., Zepeda-Jazo, I., Shabala, S., and Dobrovinskaya, O. 2014. Cross-talk between reactive oxygen species and polyamines in regulation of ion transport across the plasma membrane: implications for plant adaptive responses. Journal of Experimental Botany. 65(5), 1271-83.

Qureshi, M., Abdin, M., Ahmad, J., and Iqbal, M. 2013. Effect of long-term salinity on cellular antioxidants, compatible solute and fatty acid profile of sweet Annie (Artemisia annua L.). Phytochemistry. 95: 215-223.

Rengasamy, P., 2006. World salinization with emphasis on Australia. Journal of Experimental Botany. 57, 1017-1023.

Santana, G. S., Coelho, E. F., Silva, T.S.M., and Ramos, M.M. 2006. Estimativa da condutividadeelétrica da soluçao do solo a partir do teor de água e da condutividadeelétricaaparente do solo. EngAgrí. 26:672-685.

Shannon, M. C., 1997. Adaptation of plants to salinity. Advances in Agronomy, 60, 75120.

Shrivastava, P., and Kumar, R. 2015. Soil salinity: A serious environmental issue and plant growth promoting bacteria as one of the tools for its alleviation. Saudi Journal of Biological Sciences. 22, 123-131.

Simões, W.L., Coelho, D.S., Mesquita, A.C., Calgaro, M., and Silva, J.S.D. 2019. Physiological and biochemical responses of sugarcane varieties to salt stress, Rev. Caatinga. 32, (4), 1069 - 1076.

Srivastava, A.K., and Rai, M.K. 2012. Impact of climate change on sugarcane production, Biodiversitas. 13(4), 214-227.

Taiz, L., Zeiger, E., Moller, I., and Murphy, A. 2017. Fisiologia e desenvolvimento vegetal. 6.ed. Porto Alegre: Artmed. 888 p.

Torres-Schumann, S., Godoy, J. A., Pintor-Toro, J. A., Moreno, F. J., Rodrigo, R. M., and Garcia-Herdugo, G. 1989. $\mathrm{NaCl}$ effects on tomato seed germination, cell activity and ion allocation. Journal of Plant Physiology. 135(2), 228-232.

Verslues, P.E., Agarwal, M., Katiyar-Agarwal S., Zhu, J.H., and Zhu J.K. 2006. Methods and concepts in quantifying resistance to drought, salt and freezing, abiotic stresses that affect plant water status. Plant Journal. 45:523-539.

Wani, A. S., Ahmad, A., Hayat, S., and Tahir, I. 2016. Is foliar spray of proline sufficient for mitigation of salt stress in Brassica juncea cultivars? Environ. Sci. Pollut. Res. 23, 13413-13423.

\section{How to cite this article:}

Ranjana Singh and Sengar, R. S. 2020. Impact on Proline Content of Sugarcane (Saccharum officinarum L.) under Salinity Stress. Int.J.Curr.Microbiol.App.Sci. 9(10): 3599-3605. doi: https://doi.org/10.20546/ijcmas.2020.910.416 